\title{
THE EFFECT OF CLAY ART THERAPY ON DEPRESSION IN SCHIZOPHRENIC PATIENTS AT Dr. ARIF ZAINUDDIN PSYCHIATRIC HOSPITAL, SURAKARTA, CENTRAL JAVA
}

\author{
Rita Untari
}

Health Polytechnics, Ministry of Health, Surakarta

\begin{abstract}
Background: Depression is one of the manifestations of schizophrenic symptoms. In addition to medication, psychosocial treatment such as art therapy is essential. This study aimed to determine the effect of clay art therapy on reducing symptoms of depression in schizophrenic patients.

Subjects and Method: This was a quasi-experiment with pre post-test with no control group design, conducted in Dr. Arif Zainuddin Psychiatric Hospital, Surakarta, Central Java, from October to November 2019. A total of 26 schizophrenia patients was selected by purposive sampling. The dependent variable was depressive symptoms. The independent variable was clay art therapy. The clay art therapy was given eight times, and each session lasted 25 to 35 minutes. The depression was measured by Beck Depression Inventory-II (BDI-II) and analyzed by paired t-test.

Results: Depressive symptoms score after intervention (Mean $=19.15 ; \mathrm{SD}=10.66)$ was lower than before intervention (Mean $=26.88 ; \mathrm{SD}=10.24$ ) and it was statistically significant $(\mathrm{p}<0.001)$
\end{abstract}

Conclusion: Clay art therapy is effective for reducing depressive symptoms.

Keywords: Schizophrenia, clay art therapy, depressive symptoms

\section{Correspondence:}

Rita Untari. Health Polytechnics, Ministry of Health, Surakarta. Jl. Letjen Soetoyo Mojosongo, Surakarta, Central Java. Email: ritauntari@gmail.com. Mobile: +628164278544. 